Apidologie, 1984, 15 (1), 83-88.

RAPID COMMUNICATION

\title{
HERITABILITY FOR SIZE IN THE MEGACHILID BEE OSMIA LIGNARIA PROPINQUA CRESSON
}

V.J. TEPEDINO *, R. THOMPSON ** and P.F. TORCHIO *

* Bee Biology \& Systematics Laboratory, Agricultural Research Service, USDA

Utah State University, UMC 53 Logan, Utah 84322

$\because:$ A.R.C. Unit of Statistics, Univ. of Edinburgh, Edinburgh, EH9 3J2. Scotland

\begin{abstract}
SUMMARY
Heritability (narrow sense) for size in the blue orchard bee, $O$. lignaria, was estimated with a maximum likelihood method by weighing and releasing marked bees into a greenhouse provided with nesting material and excess bloom. Parentage of all offspring was recorded during frequent daily observations of nesting blocks throughout the nesting period. Progeny were weighed after reaching adulthood. Heritability was higher for male offspring $(0.34)$ than for females $(0.15)$ but there was no significant difference between them. Because of the low heritability for size among females, we conclude that a selective breeding program to increase size in this bee of potential commercial importance would be unprofitable.
\end{abstract}

\section{INTRODUCTION}

Because of the importance of bees as manageable pollinators of agricultural crops, genetics of bees has been studied more intensively than most other insect groups. Much of this work has focused on characteristics of the honey bee, Apis mellifera L., that relate directly to its improvement, through selective breeding, as a pollinator of specific crops and as a producer of honey (for reviews see Rothenbuhler et al., 1968 ; Kerr, 1974). Thus, Soller and Bar-CoHen (1967) found fairly high heritability (additive genetic variance) for several measures of honey production, and MACKENSEN and Nye (1966) ; NyE and MACKensen (1968) reported success in breeding honey bees with a preference for collecting alfalfa pollen.

Species of bees other than the honey bee are being recognized as potential crop pollinators with increasing frequence (PARKER and TORCHIO, 1980). Among 
these is the blue orchard bee, Osmia lignaria propinqua Cresson (Megachilidae), a species distributed throughout the western United States which nests gregariously in pre-existing holes in wood, and which appears to have exceptional potential as a pollinator of certain orchard crops (TORCHIO, $1982 \mathrm{a}, \mathrm{b}$ ). Individuals of this species vary considerably in size and size has been related to fitness in bees in the following ways : 1) TEPEDINO and TORCHIO (1982) found that large size was associated with decreased overwintering mortality in $O . l$. propinqua ; 2) PYKE (1978) suggested that large individuals fly faster than smaller forms and thereby visit more flowers per unit time ; 3) STEPHEN and OSGood (1965) indicate that large bees may be capable of carrying larger pollen and nectar loads and therefore visit more flowers per foraging trip. Thus size is potentially related to several characteristics which would enhance the performance of $O$. lignaria as a commercial pollinator. Therefore, it is important to know the magnitude of size heritability in this species to determine the feasibility of a selective breeding program.

\section{METHODS}

Bees were obtained as immatures from a native population in a canyon near Logan, Utah in 1978 and stored over winter at $4-5^{\circ} \mathrm{C}$. The following spring, they were weighed $(0.1 \mathrm{mg})$, incubated, marked with unique spots of enamel paint, and released into a greenhouse $(15.2 \times 7.6 \mathrm{~m})$ at Utah State University. Only female bees were marked. The greenhouse was stocked with 400 potted plants of Phacelia tanacetifolia Benth. (Hydrophyllaceae), a species readily used by $O$. lignaria for pollen and nectar. Three redwood blocks with 50 holes drilled in each and lined with paper straws $(15 \mathrm{~cm}$ deep $\times 7 \mathrm{~mm}$ inside diameter) were supplied as nesting materials.

Nesting blocks were observed frequently throughout each day of the flight period and the female parent of each nest recorded. Nests were stored at room temperature at the end of the flight period. Offspring were weighed in their cocoons and their sex determined in fall after' development to the adult stage was completed. For further details, consult TePEDino and Torchio (1982); the biology of O. lignaria has been described by RUST (1974).

BoHidar (1964) has discussed expectations of variances and covariances under a simple sexlinked genetic model appropriate to the megachilid bee. He shows that the expectations are functions of phenotypic variances of the parents, $\sigma_{\mathrm{p}}^{2}$, female offspring, $\stackrel{2}{\sigma_{\mathrm{OF}}}$, male offspring, $\boldsymbol{\sigma}_{\mathrm{OM}}^{2}$, the additive genetic variance in females and males $\sigma_{A F}^{2}$ and $\sigma_{A M}^{2}$ and an additive covariance between female and males $\underset{\sigma_{A M F}}{\stackrel{4}{m}}$ and a dominance covariance in females $\underset{\sigma_{D F}^{2}}{2}$. Table 1 gives expectations of the five covariances available from the data in terms of the genetic parameters.

A maximum likelihood procedure that made efficient use of the unbalanced data was used to estimate the parameters. SCHAEFFER, Wilton and THOMPson (1978) consider the case when data are available on two sexes. Their procedure would allow efficient estimation of the female and male

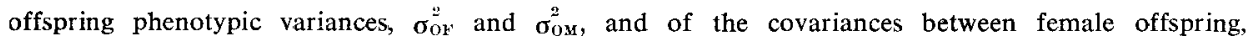
between male offspring and between female and male offspring, $\mathrm{COV}_{\mathrm{FF}}, \mathrm{COV}_{\mathrm{MM}}$ and $\mathrm{COV}_{\mathrm{FM}}$. If parents are thought of as a third sex then a direct extension of the SCHAEFFER et al. procedure would allow efficient estimation of the 5 parameters estimated from the two sex procedures and also the phenotypic variance of parents $\sigma_{\mathrm{p}}^{\mathrm{o}}$ and the covariances between parents with female and male offspring, $\mathrm{COV}_{\mathrm{PF}}$ and $\mathrm{COV}_{\mathrm{PM}}$. The 5 covariances, $\mathrm{COV}_{\mathrm{FF}}, \mathrm{COV}_{\mathrm{MM}}, \mathrm{COV}_{\mathrm{FM}}, \mathrm{COV}_{\mathrm{PF}}$ and $\mathrm{COV}_{\mathrm{PM}}$, can be expressed as linear combinations of the four genetic variances and covariances of interest (Table 1) and so estimating equations for the genetic parameters can be derived from those for the 
five covariances. Direct extension of the formulae of ScHAEFFER ef al. allow calculation of the variances and covariances of the estimates of the phenotypic variances and the genetic variances and covariances. Estimates of heritability were calculated as $h^{2}=\sigma_{A F}^{2} / \sigma_{o r}^{2}$ and $h^{2}=\sigma_{A M}^{2} / \sigma_{o x}^{2}$. If the data were balanced the structure of the data is such that $\sigma_{\mathrm{AF}}^{2}$ would be estimated from twice the covariance between parent and female offspring and $\sigma_{i \mathrm{M}}$ from twice the covariance between male offspring (Table 1).

Variances of $h^{2}$ and their differences were calculated with formulae from KEMPTHORNE (1957, p. 246).

TabL. 1. - Expectation of covariances in terms of genetic parameters

\begin{tabular}{|c|c|c|}
\hline Covariance & Symbol & Expectation \\
\hline Between female offspring & $\operatorname{cov}_{\mathrm{HF}}$ & $3 / 4 \sigma_{\mathrm{Ar}}^{2}+1 / 4 \sigma_{\mathrm{DW}}^{2}$ \\
\hline Between male offspring & $\operatorname{cov}_{111}$ & $1 / 2 \sigma_{\mathrm{AM}}^{2}$ \\
\hline Between female and male offspring & $\mathrm{COV}_{\mathrm{FM}}$ & $1 / 4 \sigma_{\text {AMF }}^{2}$ \\
\hline Between parent and female offspring & $\operatorname{COV}_{\mathrm{P}^{\mathrm{r}} \mathrm{F}}$ & $1 / 2 \sigma_{A F}^{2}$ \\
\hline Between parent and male offspring & $\operatorname{COV}_{\mathbf{P M}}$ & $1 / 2 \sigma_{A M F}^{2}$ \\
\hline
\end{tabular}

\section{RESULTS}

Seventeen female parents nested successfully in the greenhouse. Of these, 12 produced both male and female progeny, while the remaining 5 females produced only male progeny. The number of progeny produced per female ranged from 5 to 35 males, and from 0-16 females. A total of 269 males and 93 females were produced (see Tipedino and TORCHIO, 1982, for further details).

Although the value of heritability for size was larger for male progeny $\left(\mathrm{h}^{*}=0.34, \mathrm{var}=0.020, \mathrm{~N}=17 \%\right.$ parents $)$ than for female progeny $\left(\mathrm{h}^{2}=0.15\right.$, var $0.091, \mathrm{~N}=12$ \% parents), these values were statistically indistinguishable $(\mathrm{z}=-0.623, \mathrm{P}>0.25)$. Male $\mathrm{h}^{2}$ was, however, significantly different from zero $(\mathrm{z}=2.43, \mathrm{P}=0.015)$ whereas female $\mathrm{h}^{2}$ was not $(\mathrm{z}=0.50, \mathrm{P}, 0.25)$.

\section{DISCUSSION}

These results suggest that the contribution of additive genetic variance to size determination in $O . l$. propinqua is relatively small and that a selective breeding program to increase size would probably be unprofitable. This conclusion 
should be tempered by results from studies of the honey bee which have shown much higher size resemblance between parents and offspring. For example, RoBERTS (1961) found intraclass correlations of lengths of several morphological characters to be relatively high. Thus, it is possible that weight, the measure of size used in this study, is a less accurate and more variable estimator of overall size than are other measures. In addition, our sample size of parents was relatively small; an increase in the number of parents monitored would undoubtedly have increased the accuracy of our estimates. Such a study would be difficult to conduct with this bee, however, because an increase in the number of parents would greatly increase the amount of observation time necessary to accurately record parentage of offspring.

Nonetheless, our conclusion that a selective breeding program would meet with marginal success seems warranted, particularly for females whose $\mathrm{h}^{2}$ for size was very low. For pollination purposes, females are the sex of special interest because of their pollen collecting activities. It is also relevant to note that estimates of heritability are expected to be highest when all parents and offspring are subject to the same environmental conditions (FALCONER, 1981) as in this study. Thus, our estimates of $h^{2}$ are probably upper bounds.

\title{
ACKNOWLEDGEMENTS
}

We were ably assisted in our observations and tabulation of data by Glen Trostle, Kathy Ruggeri and Janie Higginson. Dr. D.V. Sisson provided statistical help to the senior author. We thank Drs. W. Rothenbuhler and J. Bowman for their appraisal of the manuscript.

Received for publication in April 1983. Accepted for publication in October 1983.

\author{
RESUME \\ HERITABILITE DE LA TAILLE CHEZ L'ABEILLE \\ OSMIA LIGNARIA PROPINQUA. (HYM., MEGACHILIDAE)
}

L'héritabilité (sens strict) de la taille chez l'abeille O. lignaria a été évaluée par la méthode de la probabilité maximum en pesant et relâchant des abeilles marquées à l'intérieur' d'une serre, dans laquelle étaient disposés du matériel pour nidifier et des fleurs de Phacelia tanacetifolia en grand nombre. L'origine parentale de toute la descendance a été suivie durant toute la période de nidification par des observations journalières fréquentes des blocs de nidification. Les descendants étaient pesés après avoir atteint l'âge adulte. L'héritabilité chez la descendance mâle $(0,34)$ est plus élevée que chez les femelles $(0,15$, mais la différence entre les deux sexes n'est pas significative. En raison de la faible héritabilité de la taille chez les femelles, on estime qu'un programme de sélection en vue d'augmenter la taille de cette abeille, qui possède une valeur commerciale potentielle élevée, ne présenterait pas d'intérêt. 


\section{ZUSAMMENFASSUNG}

\section{HERITABILITÄT DER GRÖSSE BEI OSMIA LIGNARIA PROPINQUA CRESSON (HYM,, MEGACHILIDAE)}

Die Heritabilität (im engeren Sinne) der Grösse von Osmia lignaria wurde mit der «maximum likelihood »-Methode bestimmt. Dazu wurden markierte Bienen gewogen und in ein Gewächshaus mit Nestmaterial und einem Überangebot an Blüten (Phacelia tanacetifolia) entlassen. Die Eltern aller Nachkommen wurden durch tägliche Kontrollen der Nestanlagen während der gesamten Brutperiode bestimmt. Die Nachkommen wurden im adulten Stadium gewogen. Die Heritabilität war bei männlichen Nachkommen größer $(0.34)$ als bei weiblichen $(0.15)$, die Differenz zwischen den Gesch'echtern aber nicht signifikant. Aufgrund der geringen Heritabilität der Größe bei weiblichen Tieren halten wir ein Zuchtprogramm zur Größenzunahme dieser Biene mit hohem kommerziellem Wert für unprofitabel.

\section{REFERENCES}

Bohidar N.R., 1964. - Derivation and estimation of variance and covariance components associated with covariance between relatives under sexlinked transmission. Biometrics, 20, 505-521.

Falconer D.S., 1981. - Introduction to quantitative gentetics. 2nd Ed. Longman, London.

Kempthorne O., 1957. - An introduction to genetic statistics. Wiley \& Sons, New York.

KErr W.E., 1974. - Advances in cytology and genetics of bees. Annu. Rev. Entomol., 19, 253-268.

MACKENSEN O. and NYE W.P., 1966. - Selecting and breeding honeybees for collecting alfalfa pollen. J. Apic: Res., 5, 79-86.

NyE W.P. and MACKENSEN O., 1968. - Selective breeding of honeybees for alfalfa pollen : Fifth generation and backcrosses. J. Apic. Res., 7, 21-27.

Parker F.D. and Torchio P.F., 1980. - Management of wild bees. Beekeeping in the United States. U.S. Dept. Agric., Agric. Hdbk. No. 335, Washington, D.C.

PIKE G.H., 1978. - Optimal body size in bumble bees. Oecologia, 34, 255-266.

Roberts W.C. 1961. - Heterosis in the honeybee as shown by morphological characters in inbred and hybrid bees. Ann Entomol. Soc. Am., 54, 878-882.

Rothenbuhler W.C., Kulincevic J.M. and Kerr W.E., 1968. Bee genetics. Annti. Rev. Genet., 2. $413-438$.

RUsT R.W., 1974. - The systematics and biology of the genus Osmia, subgenera Osmia, Chalcosmia, and Cephalosmia (Hymenoptera: Megachilidae). Wasmann J. Biol., 32, 1-93.

SCHAEFFER L.R., Wilton J.W. and ThOMpson R., 1978, - Simultaneous estimation of variance and covatiance components from multitrait mixed model equations. Biometrics, 34, 199-208.

Sol.ler M. and BAR-CoHen R., 1967. - Some observations on the heritability and genetic correlation between honey production and brood area in the honeybee. J. Apic. Res., 6, 37-43.

Stephen W.P. and Osgood C.E., 1965. - Influence of tunnel size and nesting medium on sex ratios in a leaf-cutter bee, Megachile rotundata. J. Econ. Entomol., 58, 965-968.

Tepedino V.J. and Torchio P.F., 1982. - Phenotypic variability in nesting success among Osmia lignaria propinqua females in a glasshouse environment (Hymenoptera : Megachilidae). Ecol. Entomol., 7, 453-462.

Torchio P.F., 1982 a. - Field experiments with Osmia lignaria propinqua Cresson as a pollinator in almond orchards : III, 1977 studies (Hymenoptera : Megachilidae). J. Kansas Entomol. Soc., 55, $101-116$.

Torchio P.F., 1982 b. - Field experiments with the pollinator species, Osmia lignaria propinqua Cresson, in apple orchards : II, 1976 studies (Hymenoptera : Megachilidae). J. Kansas Entomol. Soc., 55, 759-778. 